УДК 679.8.02

DOI: https://doi.org/10.26642/ten-2021-1(87)-169-182

\author{
В.I. Шамрай, к.т.н., доц. \\ В.В. Коробійчук, д.т.н., проф. \\ I.В. Леонець, аспірант \\ Державний університет «Житомирська політехніка»
}

\title{
Оцінка оптичних показників поверхні природного каменю методом інфрачервоної спектроскопії
}

\begin{abstract}
Збереження та вдосконалення показників якості будь-якої продукиії є актуальною науковою та практичною задачею для поточного виробництва, враховуючи вироби з природного облищювального каменю. У світі немає подібних родовищ природного облицювального каменю. Кожен з них є по-своєму неповторним. Однак для більшості родовищ природного каменю характерна природна мінливість якісних показників. Насамперед після обробки таких каменів з'являються відмінності у кольоровому тоні.

Можливо надати інший кольоровий тон хімічною обробкою. В даний час існує багато хімічних методів обробки природного каменю. Однак більщість з них недостатньо вивчена. Тому оцінку впливу хімічної обробки на поверхню природного каменю досліджували за допомогою інфрачервоної спектроскопії. Встановлено лінійні закономірності зміни колірних показників природного каменю залежно від його початкових показників після хімічної обробки на прикладі Покостівського гранодіориту (Grey Ukraine) та Буківського габро (Galant).

Окрім методу колірної сегментації, для оцінки відмінностей у типах природного облицювального каменю був використаний метод інфрачервоної спектроскопії, який показав, щяо Покостівський гранодіорит (Grey Ukraine) та Буківський габро (Galant) мають однакові довжини хвиль, щуо належать до спільного породоутворюючого мінералу - плагіоклазу. Зміна поглинання інфрачервоного випромінювання зумовлена ефектом порожнин і об' ємним розсіюванням променів y зв'язку з переходом через кристалізовану плівку хімічних просочувальних речовин. Для певного типу природного каменю зміна поглинання буде більшою чи меншою при використанні певного виду хімічної обробки, щзо вказує на міџний або слабкий зв'язок хімічних просочуючих речовин 3 поверхнею природного каменю відповідно.
\end{abstract}

Ключові слова: просочення; колір природного каменю; природний облицювальний камінь; інфрачервоний аналіз каменю; хімічна обробка.

Актуальність теми. Природний облицювальний камінь $є$ важливою складовою світової економіки в галузі будівництва. Досліджено, що 34,5 \% природного облицювального каменю використовується в облицюванні будівель. Інші сфери використання природного каменю - це монументальне будівництво, виробництво бруківки тощо. В Україні використання природного облицювального каменю нижче, ніж у $€ C$, через низьку собівартість його виробництва (коливається від 20 до 60 дол./м²). Виробництво облицювальної продукції забезпечується основними великими підприємствами проєктною потужністю від 50 до 100 тис. м²/рік, зосередженими в логістичних центрах сировинної бази України.

Стандартні методи оцінки якості поверхні природного каменю засновані на використанні суб'єктивних методів: органолептичної оцінки кольору, структури та текстури. Однак широко застосовуються об'єктивні методи: цифрова обробка зображення для визначення структури та кольору, вимірювання блиску за допомогою вимірювального приладу. Ці методи $є$ досить доступними і можуть бути використані підприємствами для точної характеристики показників якості природного каменю.

Природний облицювальний камінь характеризується мінливістю якісних показників під час його видобутку. Встановити візуальну різницю між необробленими блоками 3 природного каменю 3 різними кольоровими тонами дуже важко. У роботі [1] було знайдено рішення цієї проблеми за допомогою експресметоду, заснованого на методі кольорової сегментації. Зміна кольорових показників природного каменю характеризується різницею мінералогічного та хімічного складу каменю.

Можна використовувати хімічні просочувальні засоби, а також різні механічні інструменти для шліфування та полірування природного каменю, щоб вирівняти його колірний тон. У роботах [2-3] зміна блиску та світлості визначалася залежно від типу хімічної чи механічної обробки відповідно до типу каменю в кольоровому тоні. Механічні методи обробки природного каменю достатньо досліджені. Так за допомогою мікроскопії та спектрального аналізу в роботах [4-5] вивчається формування мікроструктури породоутворюючих мінералів. Залежно від мікротвердості гранітів експериментально досліджено процеси абразивної обробки [6]. Залежно від шорсткості поверхні каменю було вивчено зміну блиску його поверхні [7]. 
Що стосується хімічної обробки, то більшість досліджень присвячена вивченню мікроструктури, стійкості до корозії, розробці нових хімічних засобів для обробки та захисту поверхні природного каменю, переважно карбонатного складу [8-10].

Велика кількість комерційних торгових марок хімічних просочувальних засобів не інформує про хімічний склад цих продуктів і не описує наслідків взаємодії з певними мінералами та хімічними елементами, які можуть виникнути на обробленій поверхні каменю. В результаті такої обробки можуть виникнути корозійні процеси, які впливають на стійкість та декоративність природного каменю. Використання інфрачервоного аналізу під час дослідження зразків, що обробляються по-різному, дозволяє уникнути неефективного використання хімічних просочувальних засобів для поверхневої обробки природного каменю. Також використання цього методу дає змогу охарактеризувати механізм дії певних видів хімічних просочувальних засобів, знайти вміст основних компонентів та отримати детальні рекомендації щодо їх використання для певних видів природного каменю. Однак основна проблема використання інфрачервоного аналізу поверхні природного каменю полягає у зниженні надійності отриманих даних, оскільки під час вивчення природного каменю, що містить декілька основних утворюючих мінералів, отримано різні значення піків довжини хвилі, пов'язані з відповідним мінералом.

Тому робота авторів [11-13] досліджує ефективність використання хімічних просочувальних засобів для захисту поверхні мармуру. Інфрачервона спектроскопія може бути використана в роботі як характеристика взаємодії типу хімічної обробки з одним із мінералів, з яких складається гірська порода, оскільки при взаємодії з іншим характер дії може бути зовсім протилежним.

Тому використання інфрачервоного аналізу типів природного каменю, які мають відмінності в кольоровому тоні, може виправдати використання відповідних хімічних просочувальних засобів для ефективної обробки поверхні природного каменю та для запобігання передчасного його руйнування.

Аналіз останніх досліджень та публікації, на які спираються автори. Інфрачервона спектроскопія гірських порід і мінералів становить інтерес для геологічного співтовариства ще 3 моменту його розробки в середині минулого століття $[14,15]$. Ранні наукові дослідження показали, що первинні породоутворюючі мінерали, такі як силікати та карбонати, демонструють свої відбивні властивості в тепловій частині спектра від (8,0 до 14,0 мкм [16-20]. Було розроблено декілька гіперспектральних датчиків IR, які перебувають у повітрі та в космосі, враховуючи, серед інших, HyspIRI та AisaOWL. Для перевірки та калібрування даних цих датчиків були побудовані польові та лабораторні гіперспектральні IR-спектрометри. Ці польові та лабораторні датчики все частіше функціонують як головний датчик організаціями у всьому світі через їх покращену зручність використання та спектральну роздільну здатність [21]. У межах цієї розробки було розроблено декілька лабораторних реєстраторів бурових сердечників для детального аналізу бурових сердечників на сантиметр до субміліметрового просторового дозволу, що породило нове поле проксимального зондування. Ці спектрометри для відображення відбиття IR мають високу просторову та спектральну роздільну здатність (система SisuRock SPECIM 3 камерою AisaOWL, Hylogger CSIRO та сканер, що розробляється в Corescan) [22, 23], і забезпечують постійний спектральний аналіз мінералогічного заглиблення тенденції без обмежень інтервалів вибірки інших методик. Однак кілька дослідницьких груп визначили проблеми з характеристиками вибірки, такими як розмір зерна, шорсткість поверхні та пористість, які можуть впливати на спектральну ознаку.

Рання робота Ліона [24] показала, що спектральний контраст мінеральних та гірських порід зменшується зі зменшенням розміру частинок. Цю роботу неодноразово підтверджували інші, наприклад, [25-29]. Однією з характеристик вибірки, яка впливає на спектральний підпис IR, є шорсткість поверхні зразка [30-32]. Кіркленд та ін. [33] проводили лабораторні вимірювання випромінювання на карбонатних відкладах, щоб показати, що мікроскопічна шорсткість поверхні вносить об'ємне розсіювання та ефект порожнини (частково захоплюючи сигнал у поверхневих порожнинах), що призводить до зниження спектрального контрасту. Osterloo та ін. [34] провели лабораторні дослідження випромінювання 3 метою вивчення впливу зміни шорсткості поверхні на спектральний підпис IR для різних типів порід. Вони показують, що для всіх досліджених типів гірських порід спектральний контраст зменшується зі збільшенням шорсткості внаслідок пропускання світла через середовище (також відомого як розсіювання об’єму), що призводить до часткової втрати енергії. Вони також показують, що спектральний контраст зменшується до досягнення певної шорсткості, після чого спектральний контраст залишається постійним або знову збільшується. Отже, ці дослідження говорять про те, що збільшення шорсткості не призводить до постійного зниження спектрального контрасту. Віднедавна дослідження на основі емісійності, проведені Hardgrove та співавт. [35] на зразках кварцу та кальциту видно, що зміни шорсткості поверхні зразка впливають на спектральну форму сигнатури. Вони показують шорсткі поверхні, за шкалою довжини хвилі, вони викликають чіткі спектральні відмінності. До того ж автори пропонують залежність між розміром кристала та шорсткістю поверхні.

Метою статті є оцінка зміни оптичних показників природного облицювального каменю, обробленого хімічними методами. 
Викладення основного матеріалу. Фізична суть визначення оптичних показників поверхні природного каменю полягає в тому, що промінь вимірювального обладнання, падаючи на поверхню мінералу, частково відбивається, заломлюється, розсіюється або поглинається. Оптичні властивості виявляються через світлозаломлення, світловідбиття, світлорозсіювання та світлопоглинання. 3 ними пов'язані забарвлення мінералів, що утворюють гірську породу, і явище люмінесценції. На оптичних властивостях грунтується методика вивчення гірських порід та породоутворюючих мінералів за допомогою різного вимірювального обладнання.

Отже, авторами пропонується провести оцінку оптичних показників поверхні природного каменю таким чином:

1. Провести оцінку колірних показників поверхні природного каменю за допомогою методу цифрової обробки зображень;

2. Провести оцінку блиску поверхні природного каменю за допомогою блискоміра;

3. Провести оцінку оптичних показників поверхні природного каменю методом інфрачервоної спектроскопії.

Підготовка зразків природного каменю для дослідження оптичних показників його поверхні

Для проведення оцінки якості використовуються зразки з Покостівського гранодіориту (Grey Ukraine) та Буківського габро (Galant) розмірами 50×50×50 мм, які були відібрані після операції полірування за допомогою алмазного інструменту. Варто зазначити, що зразки були відібрані з плит, вирізаних з одного блоку. Прожилки, плями та інші дефекти природного каменю були відокремлені 3 плит для забезпечення рівномірної структури відібраних зразків шляхом їх вирізання (рис. 1).

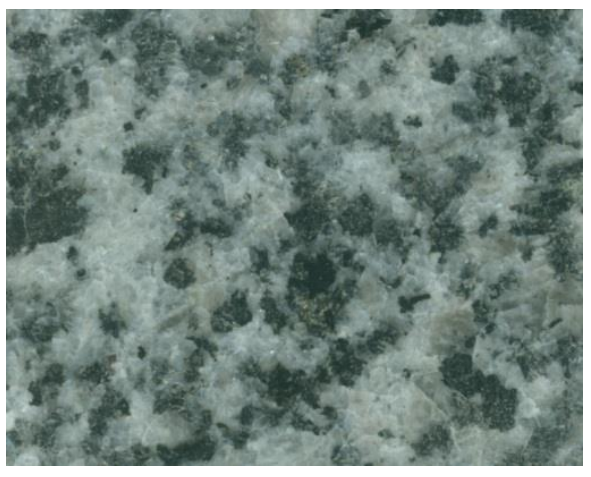

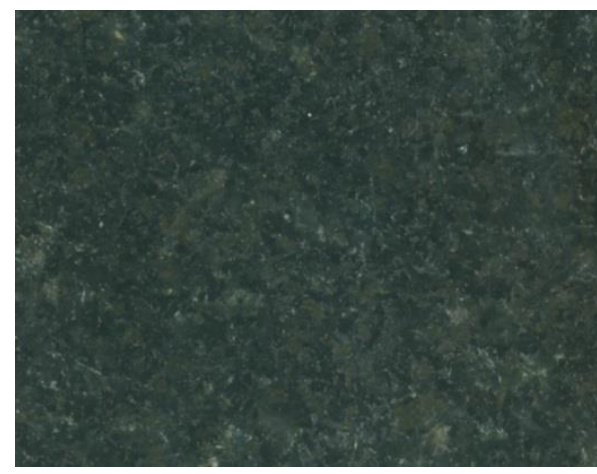

$\sigma$

Pис. 1. Зразки декоративного каменю: а-Покостівський гранодіорит (Grey Ukraine); б - Буківський габро (Galant)

В якості алмазного інструменту використовувалися фікерти з номерами та зернистістю, які показані в таблиці 1. Така схема використання алмазного інструменту дозволяє отримати якісну поліровану поверхню каменю.

Після механічної обробки поверхні зразки природного каменю було оброблено хімічно. Для цього на поліровані поверхні однаково оброблених зразків каменю були нанесені відповідні просочувальні засоби.

Як хімічні просочувальні засоби використовувалися:

1. Засіб для імпрегнації Impregnation agent 1, який надає поверхні ефект мокрого каменю та застосовується для обробки поверхні всіх видів природного каменю для захисту від вологи, масла, жиру і посилення кольору;

2. Прозорий кристалізатор - Impregnation agent 2, що застосовується для поліпшення блиску i насиченості кольору всіх видів природного облицювального каменю;

3. Кристалізатор чорного кольору - Impregnation agent 3, для виробів з натурального каменю (чорних відтінків), таких як: граніт, габро, лабрадорит. Засіб глибоко проникає і закриває пори, мікротріщини, захищаючи камінь від руйнування. Підсилює і насичує колір каменю та надає делікатний блиск;

4. Кристалізатор червоного кольору - Impregnation agent 4, для виробів з натурального каменю (червоних відтінків). Використовується з метою насичення кольору, підкреслення текстури та збільшення блиску каменю.

Всього було підготовлено по 3 механічно оброблених та по 12 хімічно оброблених зразків 3 Покостівського гранодіориту (Grey Ukraine) i така ж кількість зразків з Буківського габро (Galant). В цілому було підготовлено 30 зразків 3 природного каменю, кожні 3 зразки мали однаковий вид обробки для визначення похибок під час вимірювання. 
Визначення колірних показників поверхні природного каменю

Цифрове зображення поверхонь зразків каменю було отримано за допомогою сканера НР 3970. Виконувалося калібрування сканера за допомогою вбудованої колірної стрічки та програмного забезпечення. Визначалися середні колірні координати в системі CIELab досліджуваних поверхонь зразків у програмі Mdistones (рис. 2).

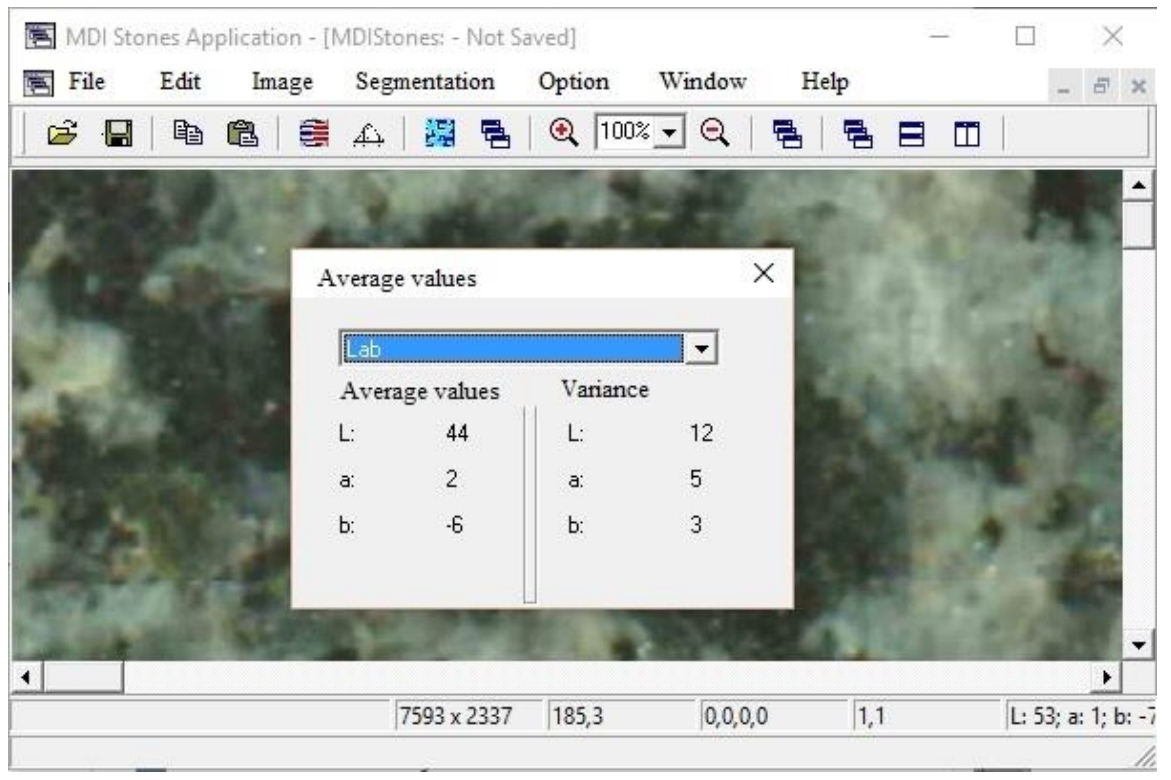

Рuc. 2. Визначення колірних показників поверхні природного каменю у програмі Mdistones

Колірна система CIELab була обрана тому, що вона була сконструйована так, що однакова кількість числових змін цих значень відповідає приблизно однаковій кількості візуально сприйнятих змін. Він виражає колір у вигляді трьох значень: L - світлість від чорного (0) до білого (100), колірні координати:

a - від зеленого (-) до червоного (+); та b - від синього (-) до жовтого (+).

Координати XYZ перетворюються в параметри CIELab згідно з такими виразами [1]:

$$
\begin{aligned}
& L=116\left(\frac{Y}{Y_{0}}\right)^{1 / 3}-16 ; \\
& a=500\left[\left(\frac{X}{X_{0}}\right)^{1 / 3}-\left(\frac{Y}{Y_{0}}\right)^{1 / 3}\right] ; \\
& b=200\left[\left(\frac{X}{X_{0}}\right)^{1 / 3}-\left(\frac{Z}{Z_{0}}\right)^{1 / 3}\right]
\end{aligned}
$$

Точність визначення колірних координат поверхні природного каменю становить 12,5-15 \%. Через наявність світлих та темних мінералів у Покостівському гранодіориті (Grey Ukraine) середня світлість поверхні природного каменю визначалась за формулою:

$$
L_{\text {avg }}=\frac{L_{1} S_{1}+L_{2} S_{2}}{100}, \%
$$

де $L_{1}, L_{2}-$ світлість чорних та білих мінералів, \%;

$S_{1}, S_{2}$ - площа чорних та білих мінералів, \%.

Для того щоб визначити вплив хімічної обробки на поверхню природного облицювального каменю, спочатку були визначені його початкові колірні показники, які змінюються в певних межах залежно від типу каменю. Наприклад, для Покостівського гранодіориту (Grey Ukraine) світлість каменю знаходиться в межах від 44 до 53, а для Буківського габро (Galant) - в межах від 24 до 32. Аналогічно межі вихідних колірних показників (a) та (b) було визначено для поверхонь двох типів природного каменю. Після хімічної обробки колірні показники поверхні природного каменю змінюються залежно від початкових. Зміни колірних показників поверхні природного каменю визначалися залежно від початкових колірних показників та лінійних закономірностей колірних координат поверхонь Покостівського гранодіориту (Grey Ukraine) та Буківського габро (Galant) після хімічної обробки (рис. 3-5). 


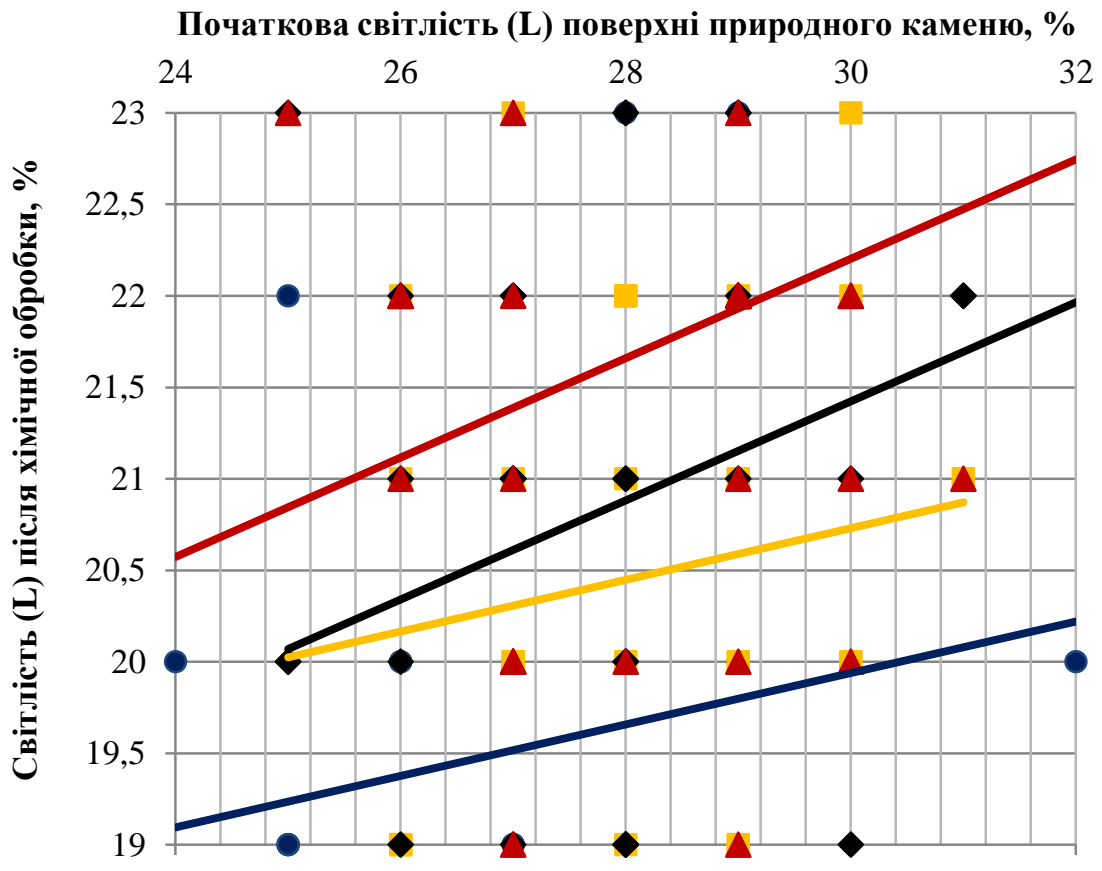

$a$

Початкова світлість (L) поверхні природного каменю, \%

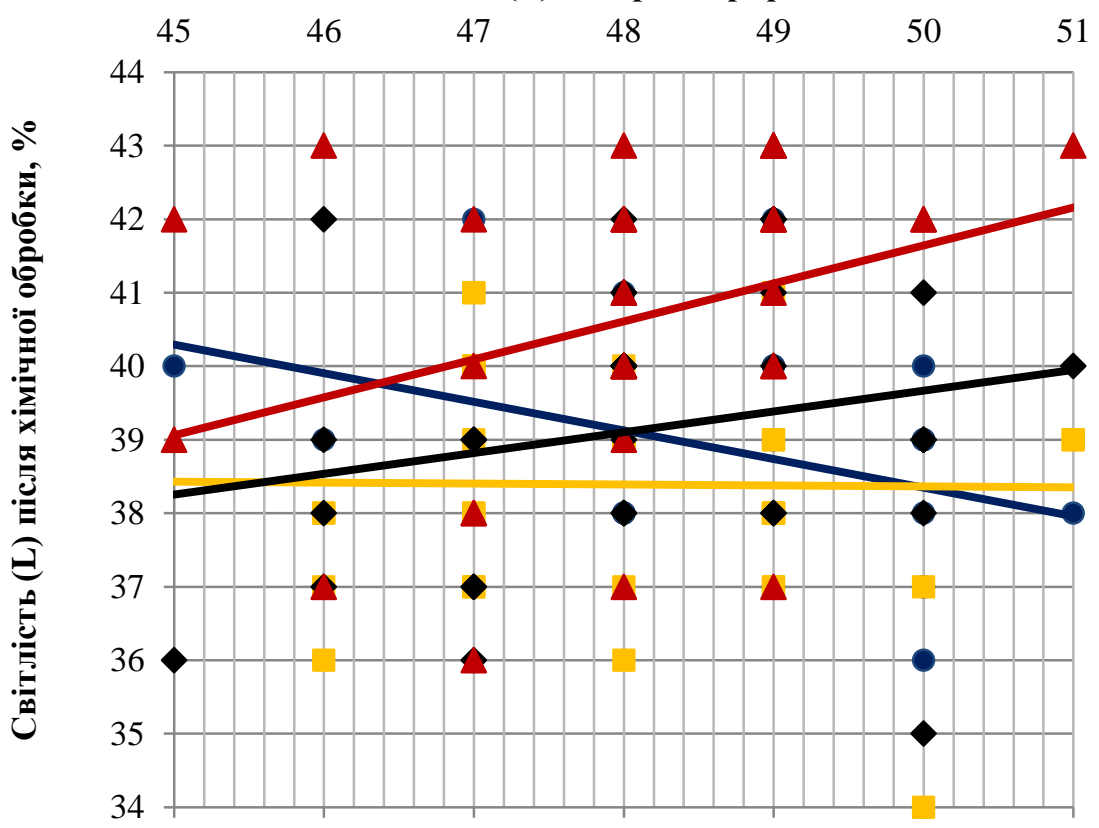

51

Impregnation agent 1

$y=-0,389 x+57,798$

Impregnation agent 2

$y=-0,0128 x+39,008$

- Impregnation agent 3

$y=0,2826 x+25,533$

$\Delta$ Impregnation agent 4

$y=0,5165 x+15,818$

$\sigma$

Puс. 3. Зміна середньої світлості (L - компонента кольорової системи Lab) поверхні природного каменю після хімічної обробки: а - Буківське габро (Galant); б-Покостівський гранодіорит (Grey Ukraine)

Відповідно до встановлених закономірностей можна визначити світлість поверхні природного каменю після хімічної обробки. Наприклад, початкова світлість Покостівського гранодіориту (Grey Ukraine) становить $45 \%$, після обробки хімічним просочувальним засобом № 4, згідно з лінійною закономірністю, його світлість буде становити 39 \% (-6 \%). При обробці Буківського габро (Galant) з початковою світлістю $32 \%$ хімічним просочувальним засобом № 3, згідно з лінійною закономірністю, його світлість буде становити 22 \% (-10\%). Встановлені лінійні закономірності показують, що зміна світлості поверхні як Покостівського гранодіориту (Grey Ukraine), так і Буківського габро (Galant) після хімічної обробки буде більшою (візуально більш помітною), ніж більша початкова величина світлості. Таким чином відбувається потемніння поверхні каменю, зменшується світлість (-L). 


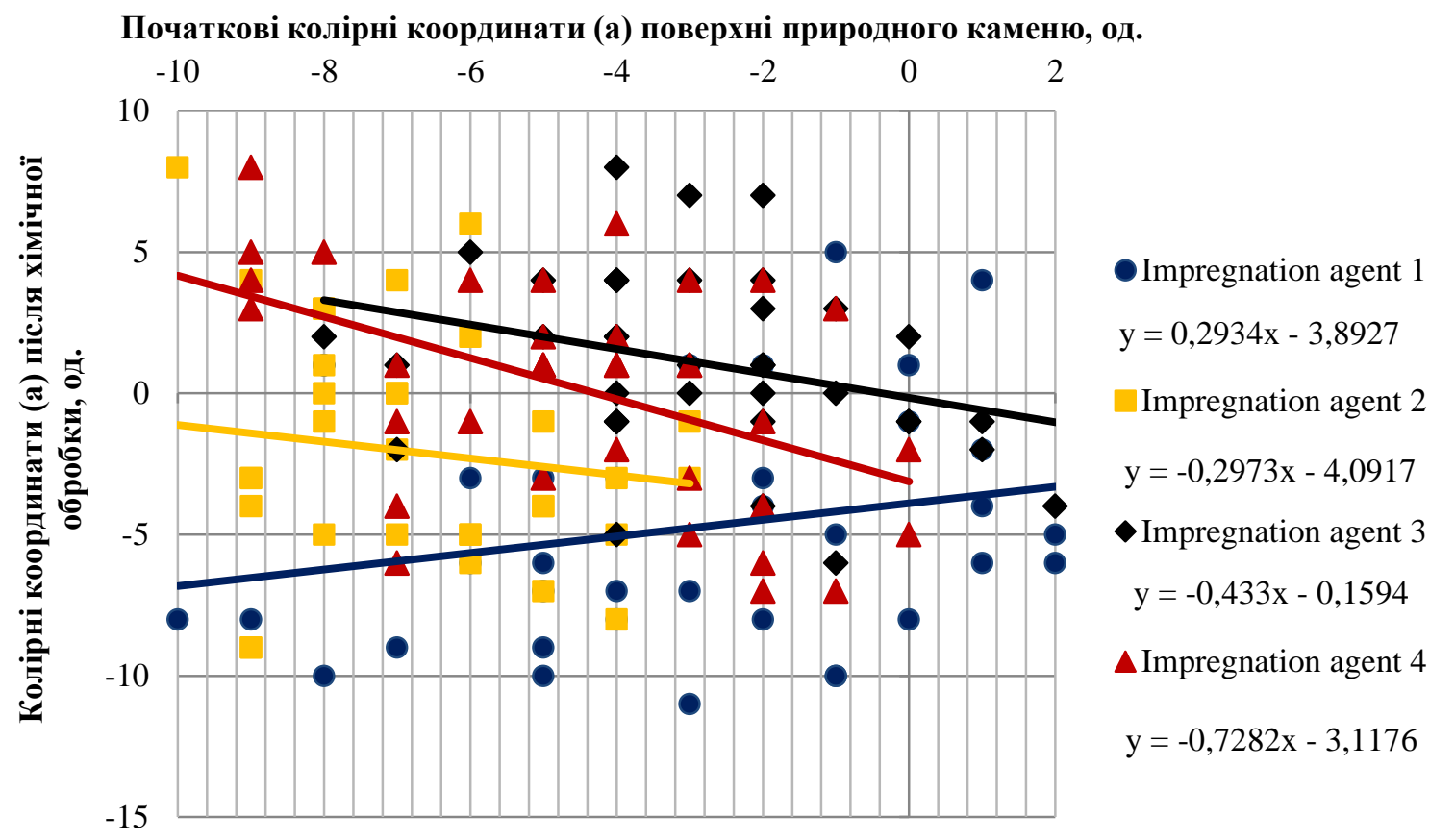

$a$

Початкові колірні координати (а) поверхні природного каменю, од.

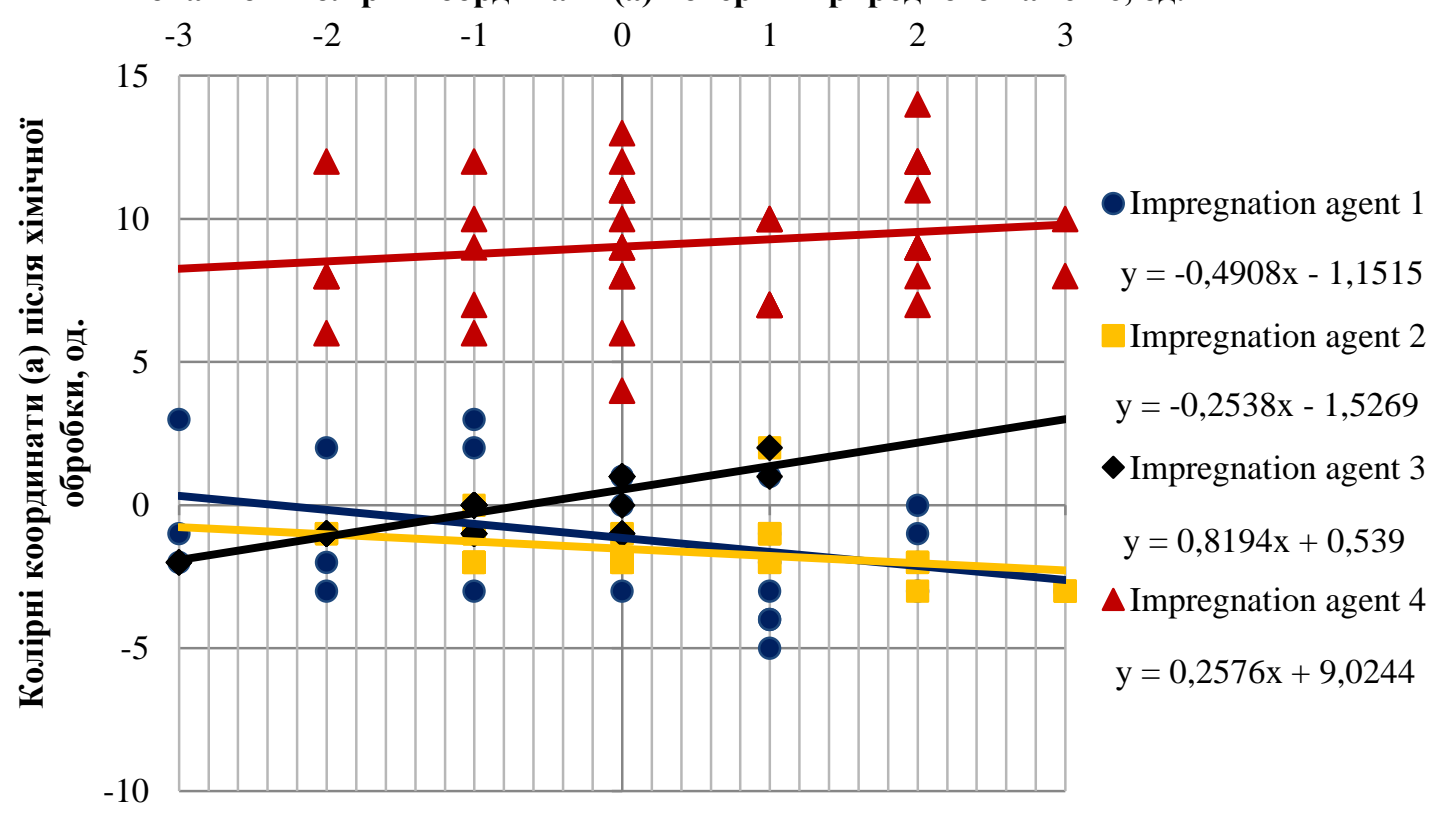

$\sigma$

Рис. 4. Зміна колірної координати (а - компонента кольорової системи Lab) поверхні природного каменю після хімічної обробки: а - Буківське габро (Galant); б - Покостівський гранодіорит (Grey Ukraine)

Аналогічно, можна визначити колірну координату (а) поверхні природного каменю після хімічної обробки. Наприклад, початкова колірна координата (а) поверхні Буківського габро (Galant) становить -10 од., після обробки хімічним просочувальним засобом № 4, згідно з лінійною закономірністю, його колірна координата (а) буде становити 4 од. При цьому зміна колірної координати (а) буде складати -14 од.). При обробці Покостівського гранодіориту (Grey Ukraine) з колірною координатою (а), що складає -3 од. хімічним просочувальним засобом № 4, згідно з лінійною закономірністю, його колірна координата (а) буде становити 8 од. (+11 од.). 
Лінійні закономірності зміни колірної координати (а) показують, що початкові «негативні» координатні дані, що характеризують зелену (-а) компоненту кольору, змінюються на червону (+a) колірну компоненту після хімічної обробки поверхні природного каменю.

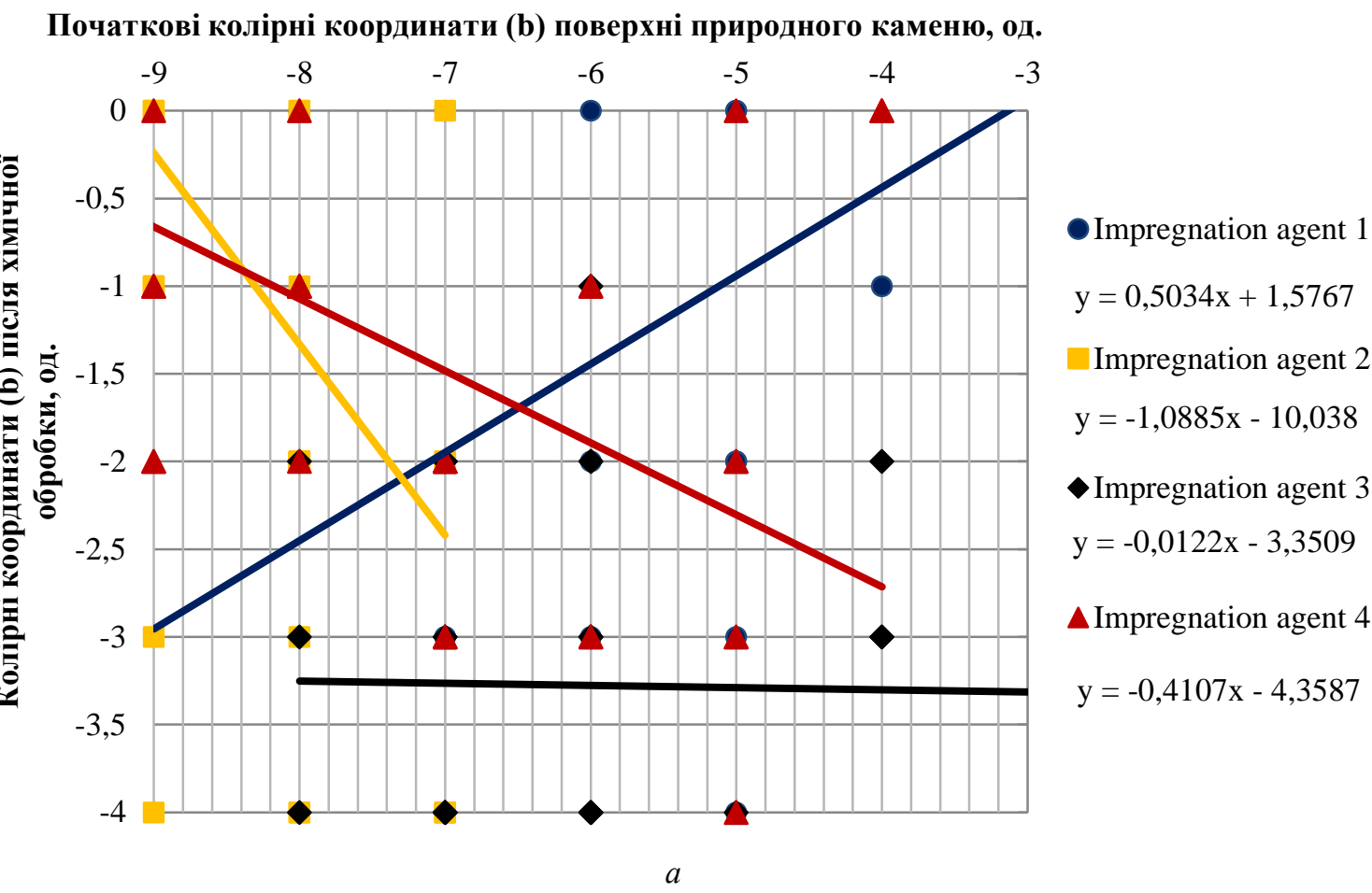

Початкові колірні координати (b) поверхні природного каменю, од.

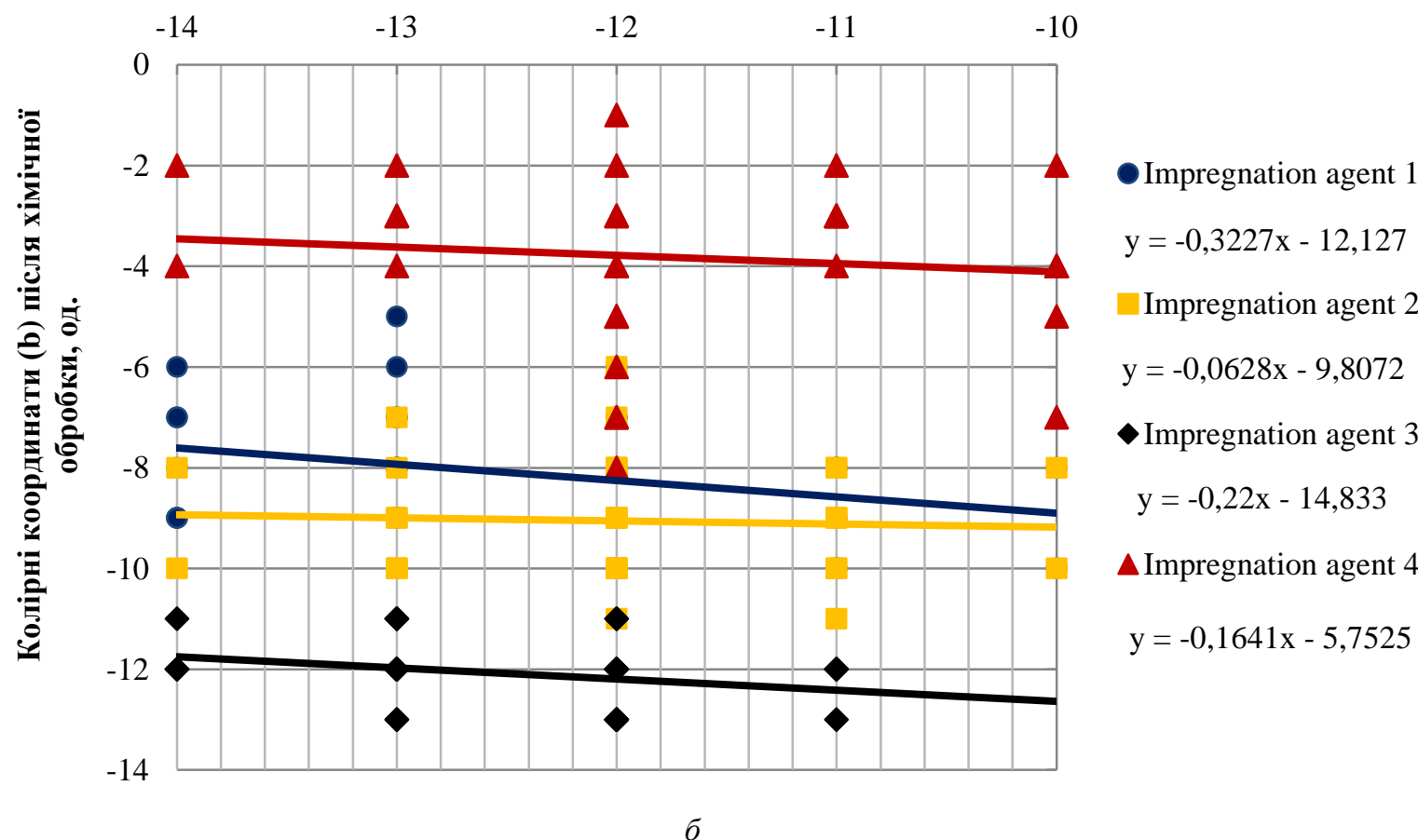

Рuc. 5. Зміна колірної координати (b - компонента кольорової системи Lab) поверхні природного каменю після хімічної обробки: а -Буківське габро (Galant);

б - Покостівський гранодіорит (Grey Ukraine) 
Аналогічно, лінійні закономірності зміни колірної координати (b) показують, що початкові «негативні» координатні дані, що характеризують синю (-b) компоненту кольору, змінюються на жовту (+b) колірну компоненту після хімічної обробки поверхні природного каменю.

Визначення блиску поверхні природного каменю за допомогою блискоміра

Відповідно до ДСТУ Б В.2.7-59-97, визначення блиску природного каменю після полірування здійснюють за допомогою блискоміра «НИИКС-БМ-3» або відповідно до ГОСТ 896 - ФБ-2. Робота всіх типів блискомірів побудована на вимірюванні блиску полірованої поверхні природного каменю та зіставленні ії з еталонною поверхнею.

Блиск природного каменю визначає його здатність до полірування, що є важливим критерієм як для декоративного, так і для дорогоцінного та напівдорогоцінного каменю. Інтенсивність блиску полірованої поверхні значною мірою залежить від текстури і структури природного каменю, його мінерального складу, міжмінерального зв'язку, обладнання і технологічних параметрів обробки каменю, інструменту та абразиву, які використовують під час його обробки, що впливає на шорсткість поверхні.

Наразі сучасні галузі виробництва все менше користуються вітчизняними стандартами ДСТУ Б В.2.7- 59-97 та ГОСТ 896, а переходять до сучасних діючих міжнародних стандартів ASTM-D523 та ISO 2813, в яких широко використовуються методи визначення блиску поверхонь за допомогою портативних сучасних блискомірів, які визначають блиск поверхні у відсотках відбитого світла, або у відносних - як відношення інтенсивності світла, відбитого дзеркально, до інтенсивності світла, відбитого дифузно. Це дозволяє уникнути похибок під час вимірювання, які виникають внаслідок наявності певної частки світла, поглинутої матеріалом.

Дослідження блиску поверхні такими блискомірами проводять під трьома кутами падіння світла $20^{\circ}$, $60^{\circ}, 85^{\circ}$. Зазвичай майже всі поверхні природного каменю вимірюються під кутом $60^{\circ}$. Якщо під час вимірювання блиску поверхні зразка під кутом $60^{\circ}$ значення блиску вище за $70 \mathrm{GU}$, рекомендується застосовувати кут $20^{\circ}$, що ідеально підходить для вимірювань в галузі з високим блиском (глянцеві поверхні). На напівматових і матових поверхнях зі значеннями менше за $10 \mathrm{GU}$ при $60^{\circ}$ рекомендується проводити вимірювання під кутом $85^{\circ}$. Таку методику визначення кута вимірювання більш детально описано в стандартах.

Принцип роботи блискоміра побудований на порівнянні блиску досліджуваної поверхні з полірованою поверхнею еталону (чорне скло), який має показник заломлення 1,540. Блиск еталонного скла для кута падіння $60^{\circ}$ становить $92 \mathrm{GU}$, а діапазон вимірювання блиску обладнання може становити залежно від моделі від 0 до 1000 GU. При цьому максимальна величина блиску досліджуваної поверхні природного каменю не перевищувала еталонної. Для характеристики видів обробки природного облицювального каменю були визначені показники блиску оброблених поверхонь Буківського габро (Galant) та Покостівського гранодіориту (Grey Ukraine) (рис. 6).

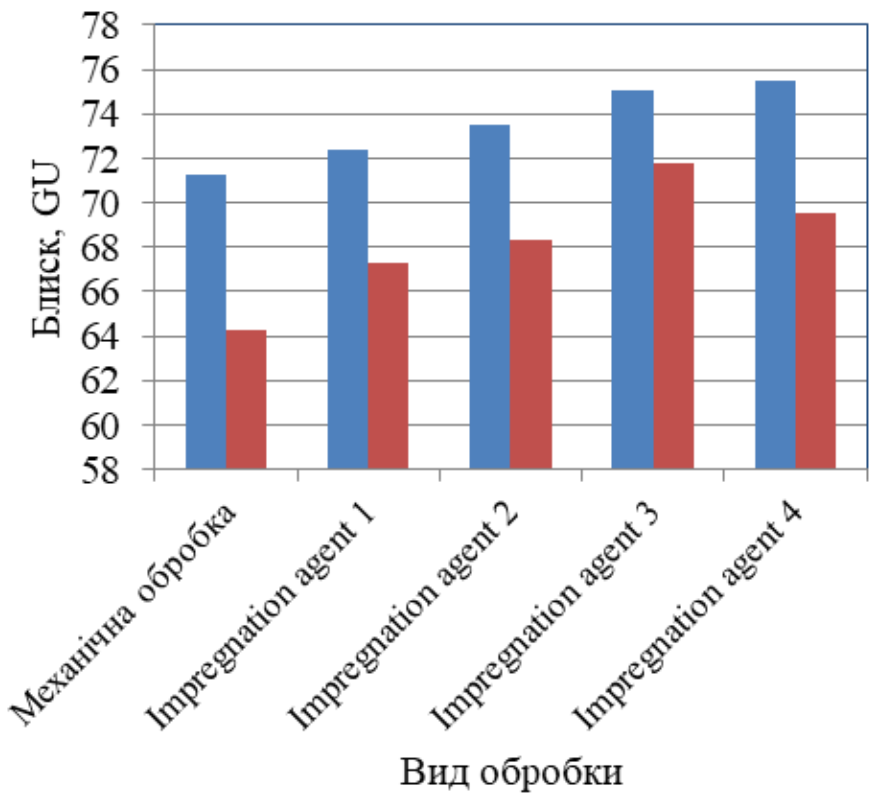

Буківське габро (Galant)

- Покостівський гранодіорит (Grey Ukraine)

Рис. 6. Значення блиску на оброблених поверхнях природного каменю 
3 рисунка 6 видно, що, на відміну від Покостівського гранодіориту (Grey Ukraine), показники блиску поверхні Буківського габро (Galant) є вищими. Після обробки хімічними просочувальними засобами поверхонь природного каменю вимірювання показали, що показники блиску є вищими, ніж після обробки поверхонь механічним способом. При цьому після обробки хімічним просочувальним засобом № 3 та 4 спостерігаються найбільші показники блиску.

Очінка оптичних показників поверхні природного каменю за допомогою інфрачервоної спектроскопії

Інфрачервону спектроскопію (ІЧ) проводили для того, щоб визначити структуру зразків природного каменю 3 різною обробкою. ІЧ-спектри зразків природного каменю вимірювали за допомогою спектрометра FTIR Bruker Tensor 27, скануючи їх у діапазоні від 4000 до 250 cм$^{-1}$, використовуючи KBr у дрейфуючому режимі для дослідження зміни зразків природного каменю після хімічної та механічної обробки.

Поверхневе відображення можна розділити на два кінцеві елементи: дзеркальне відображення гладкої поверхні з високою непрозорістю та дифузне відбиття шорсткої поверхні з постійною непрозорістю. У разі дзеркального відображення поверхня поводиться дзеркально, а кут падіння дорівнює куту відбиття, що призводить до копланарного відображення. При дифузному відбитті промені відбиваються в багатьох напрямках незалежно від кута падаючого випромінювання. Тому відбита енергія поширюється на велику кількість світлових променів, які можуть, залежно від методу вимірювання, знижувати абсолютне відбиття сигналу [36]. Більшість поверхонь не відображає дійсне дзеркальне та дифузне відображення, а суму двох кінцевих показників.

Об’ємне розсіювання відбувається тоді, коли на поверхні містяться значні кількості гіпертонких частинок (1-20 мкм), які впроваджують передачу падаючих променів через стиснуті частинки. В результаті енергія втрачається через часткове поглинання сигналу. Це впливає на спектральний підпис, що призводить до зміни форми спектра, зміщення спектральних ознак до більшої довжини хвилі та втрати спектрального контрасту або навіть інверсії спектральної сигнатури.

Поверхневі порожнини можуть захоплювати та поглинати падаючі промені, зменшуючи відбиття та супровідний спектральний контраст, явище відоме як ефект порожнини. Залежність між кількістю порожнин на поверхні та спектральним контрастом приблизно лінійна [32-34]. Факторами, що впливають на зменшення спектрального контрасту, є форма порожнини, площа порожнини, область вхідного отвору та дифузна або дзеркальна відбивна здатність стінки порожнини. Як правило, чим вище відношення глибини порожнини до ширини входу, тим значніший ефект порожнини [33; 34; 37].

Дослідження показують, що для більшості матеріалів збільшення шорсткості поверхні призводить до збільшення кількості поверхневих порожнин [33]. Результат полягає в тому, що порожнини мають протилежний ефект у вимірах випромінювання. Отже, якщо відбита енергія зменшується, енергія, що випромінюється, збільшується [38]. Критерій шорсткості Релея може бути використаний для характеристики шорсткості поверхні. Поверхня є оптично гладкою залежно від висоти топографії поверхні (різниця між найглибшою долиною та найвищою вершиною) та довжини хвилі світла та кута падаючого проміння [34, 39].

Щоб шорсткість поверхні впливала на спектральний контраст, топографія поверхні повинна бути більшою за довжину хвилі падаючих світлових променів. Поверхні діапазону IR (7-16 мкм) вважаються оптично шорсткими, коли висота топографії дорівнює або перевищує 1-20 мкм залежно від кута падіння [54]. Оптична гладка поверхня переважає поверхневим відбиттям, тоді як на оптичні шорсткі поверхні все більше впливає дифузне відбиття та розсіювання об'єму. Інфрачервона спектроскопія в основному використовується для кількісного та якісного аналізу складу різних речовин. Існує безліч перешкод для поверхневого інфрачервоного аналізу, оскільки властивості та умови випробовуваних зразків можуть бути однаковими.

Основною проблемою, що виникає під час дослідження поверхні зразків природного каменю, була неоднорідність його мінерально-хімічного складу, що розповсюджується на площу зразка. В результаті були отримані різні спектри, які важко було ідентифікувати без попередньо підготовлених контрольних зразків. Повний інфрачервоний спектр поверхні Покостівського гранодіориту (Grey Ukraine) та Буківського габро (Galant) показаний на рисунку 7. 


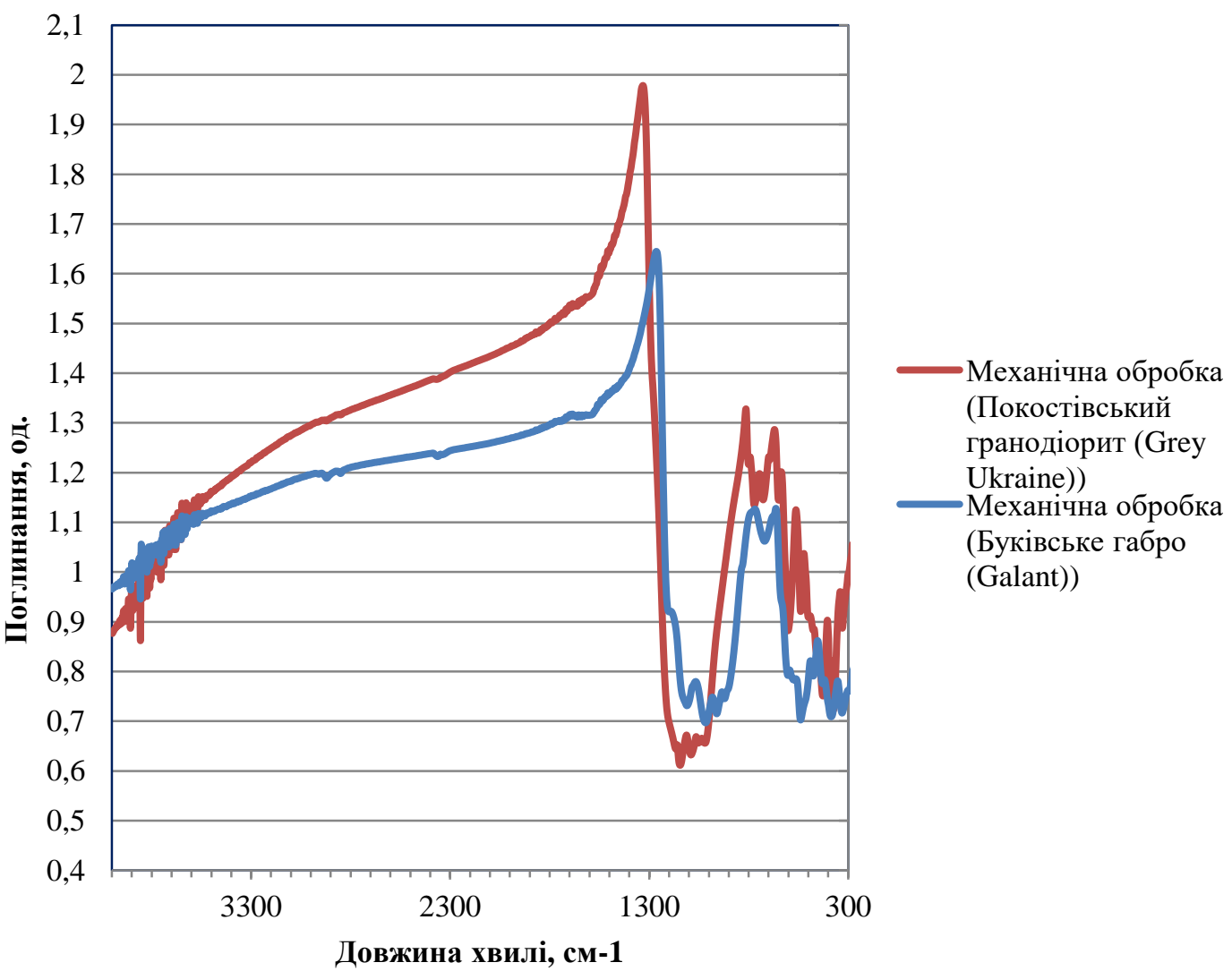

Рис. 7. Повний інфрачервоний спектр поверхні Покостівського гранодіориту (Grey Ukraine) та Буківського габро (Galant)

Розглянувши повний спектр природного каменю, ми бачимо, що велика кількість піків знаходиться в межах від $1400 \mathrm{~cm}^{-1}$ до $300 \mathrm{~cm}^{-1}$. 3 цієї причини було вирішено розглянути цей діапазон довжин хвиль, щоб виявити відмінності між цими видами каменю та визначити ефективність обробки природного каменю.

Як видно з рисунка 7, Покостівський гранодіорит (Grey Ukraine) та Буківський габро (Galant) мають різні інфрачервоні спектри, що пояснюється різницею мінералогічного складу природного каменю. Також спектр Покостівського гранодіориту (Сіра Україна) має більше піків, ніж у Буківського габро (Galant). Це тому, що в Покостівському гранодіориті (Grey Ukraine) є більше мінералів, ніж у Буківському габро (Galant). Taк Буківське габро (Galant) складається в основному з плагіоклазу та піроксену, а Покостівський гранодіоріт (Grey Ukraine) складається в основному з мікрокліну, плагіоклазу, кварцу та біотиту. Також загальним є те, що ці породи знаходяться в межах однієї геологічної зони. Породоутворюючі мінерали цих порід мають загальну довжину хвилі. Оскільки ці породи мають один загальний мінерал - плагіоклаз, аналізуючи спектри двох типів каменю, виявлено однакові довжини хвиль, що належать до плагіоклазу (табл. 1).

Табличя 1

Спектр природного каменю, який відповідає загальному мінералу - плагіоклазу

\begin{tabular}{|c|c|c|c|c|c|c|c|c|}
\hline Вид каменю & \multicolumn{8}{|c|}{ Довжина хвилі, см-⿱ / Поглинання, од. } \\
\hline Покостівський & $1112 /$ & $1064 /$ & $1020 /$ & $771 /$ & $727 /$ & $603 /$ & $540 /$ & $428 /$ \\
гранодіорит (Grey & 0,67 & 0,66 & 0,65 & 1,13 & 1,14 & 0,88 & 0,92 & 0,75 \\
Ukraine) & $1110 /$ & $1066 /$ & $1016 /$ & $769 /$ & $721 /$ & $603 /$ & $540 /$ & $430 /$ \\
0,78 & 0,69 & 1,12 & 1,06 & 0,79 & 0,7 & 0,78 \\
\hline Буківське габро & 0,73 & 0,78 & \\
(Galant) &
\end{tabular}

Однак існують також відмінності в спектрах цих типів каменю, що характеризують їх породоутворюючі мінерали. Покостівський гранодіорит (Grey Ukraine) має такі чіткі піки поглинання: $1330,1145,1089,813,746,671,649,636,563,522,405$ cм$^{-1}$ (піки мікрокліну, кварцу та біотиту). Також інші піки поглинання має Буківське габро (Galant) - 1263, 981, 960, 935, 921, 663, 489, 476, 453 см$^{-1}$ (піроксенові піки). 
У роботі [39] було розглянуто можливість ідентифікації породоутворюючих мінералів габро. Враховуючи умови підготовки зразків до геологічної оцінки, що передбачає полірування поверхні природного каменю, було встановлено, що шорсткість поверхні каменю впливає на інфрачервоні спектри зразків. Більше того, зміни поглинання викликані зміною кута відбиття інфрачервоного променя, що характеризується таким впливом:

1. Порожнинний ефект. Вплив порожнин залежить від якості полірування поверхні природного каменю (шорсткості поверхні). Якщо ІЧ-промінь потрапляє в порожнину, то поглинання збільшується. Порожнини заповнюються за допомогою хімічних просочувальних засобів, тому поглинання зменшується;

2. Об’ємне розсіювання. Розсіювання викликане проходженням ІЧ-променя через прозорий шар хімічних просочувальних речовин та зміною кута відбиття.

Відповідно, зміна спектрів поглинання після хімічної обробки буде зумовлена цими факторами. В результаті інфрачервоного аналізу поверхонь природного каменю після хімічної обробки були отримані спектри Покостівського гранодіориту (Grey Ukraine) та Буківського габро (Galant) (рис. 8). Аналізуючи піки спектрів різнооброблених поверхонь природного каменю, можна зробити висновок, що інтенсивність поглинання зменшується після хімічної обробки поверхонь природних каменів. Однак утворення нових піків спектрів не спостерігається.

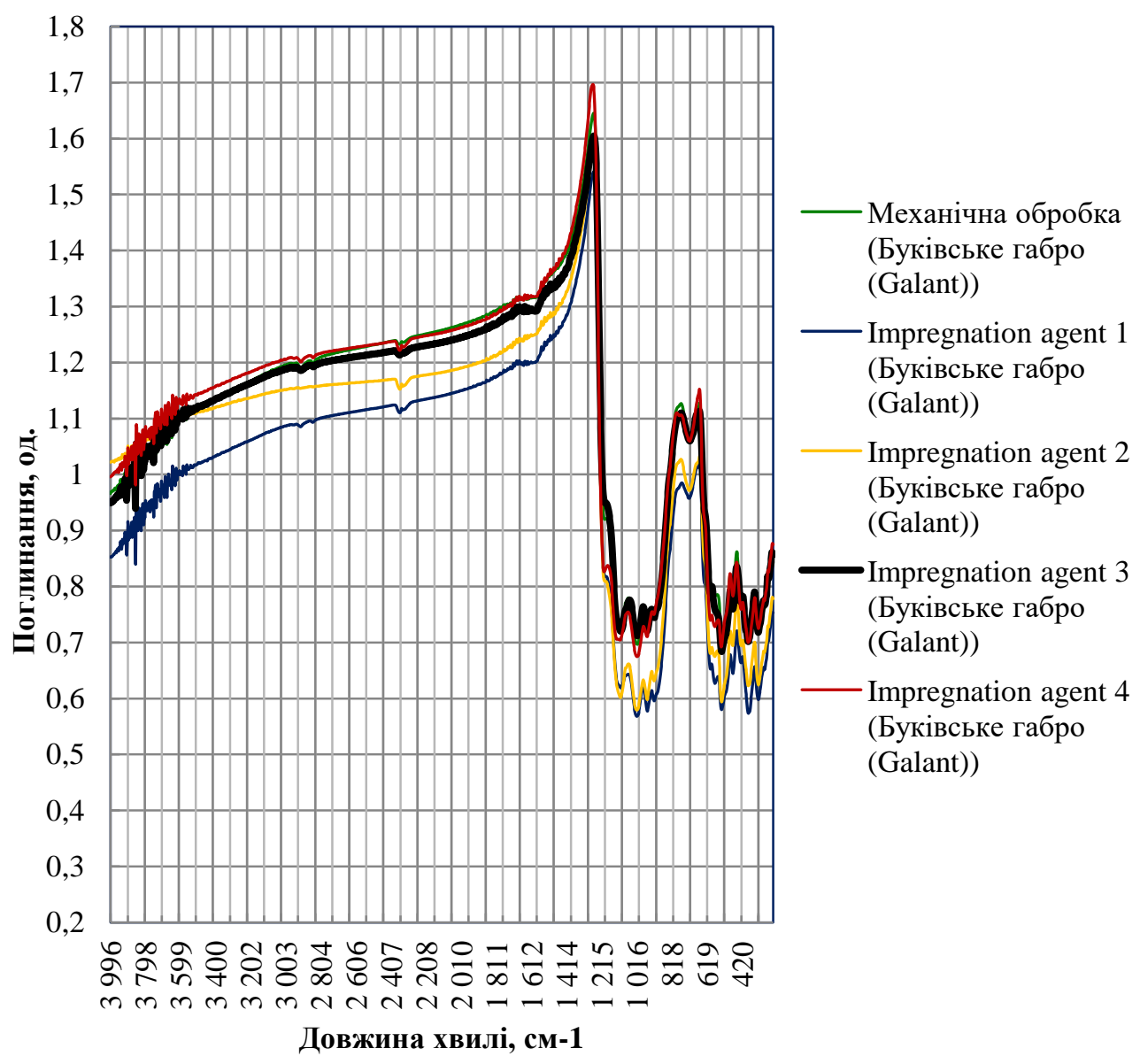




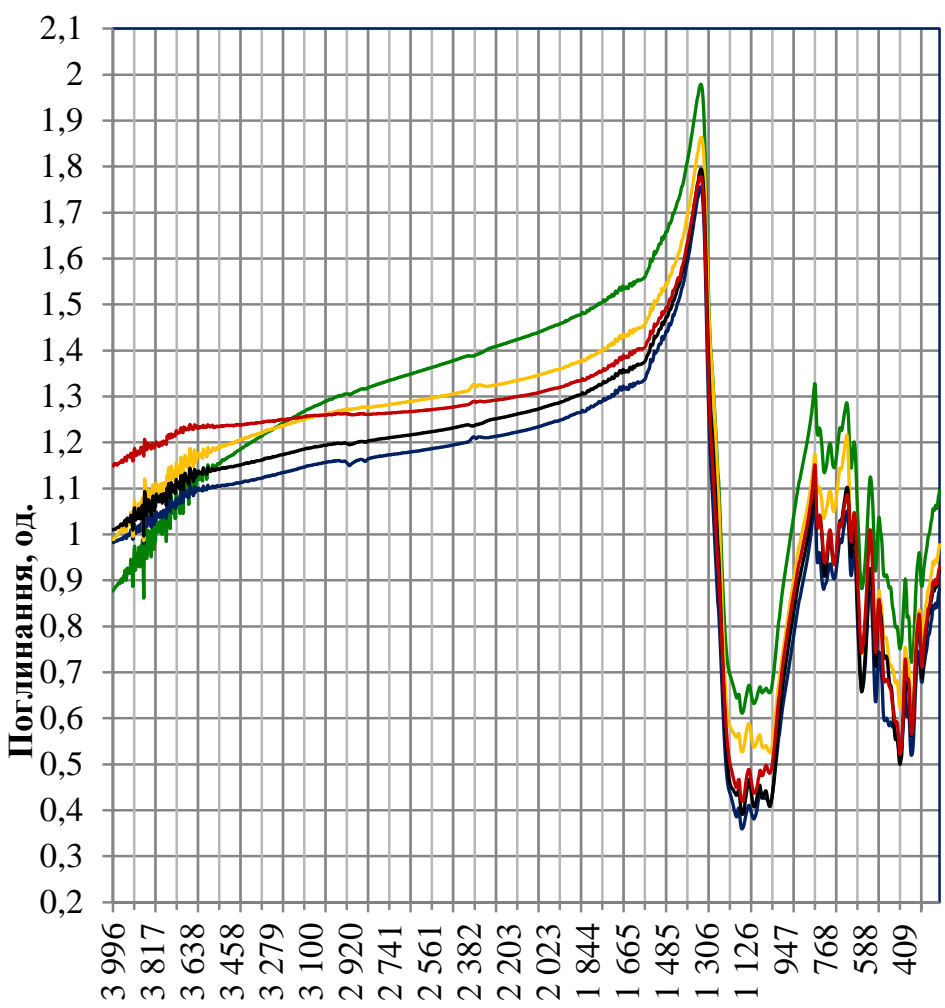

— Механічна обробка (Покостівський гранодіорит (Grey Ukraine))

- Impregnation agent 1 (Покостівський гранодіорит (Grey Ukraine))

Impregnation agent 2 (Покостівський гранодіорит (Grey Ukraine))

- Impregnation agent 3 (Покостівський гранодіорит (Grey Ukraine))

— Impregnation agent 4 (Покостівський гранодіорит (Grey Ukraine))

Довжина хвилі, см-1

Рис. 8. Зміна спектра поглинання різних типів природного каменю: а - Буківського габро (Galant); б - Покостівського гранодіориту (Grey Ukraine) після хімічної обробки

Отже, для певного типу каменю зміна спектра поглинання буде більшою чи меншою під час використання певного виду хімічної обробки, що вказує на сильну або слабку взаємодію хімічних просочуючих речовин з поверхнею природного каменю. За наявності слабкої взаємодії може спостерігатися зачистка або непокриття наноплівкою, яку утворюють хімічні просочувальні засоби (рис. 8).

Згідно з рисунком 8, ефективність хімічної обробки природного облицювального каменю зростає зі збільшенням змін поглинання спектрів природного каменю. В результаті дослідження ця зміна поглинання пояснюється наявністю шорсткості поверхні природного каменю. Також траплялися явища, що впливали на спектри матеріалу [55]. Також не виявлено нових піків спектрів поверхонь природного каменю після хімічної обробки. Це свідчить про те, що хімічна обробка не призводить до утворення нових речовин. Вона утворює наноплівку, яка заповнює мікронерівності поверхні природного каменю. Отже, під час дослідження поверхні зразків природного каменю після хімічної обробки методом інфрачервоної спектроскопії зміна спектрів поглинання характеризується особливістю проходження інфрачервоного променя через шар хімічної обробки. Якщо зміни спектрів поглинання хімічно оброблених зразків не спостерігаються, це вказує на відсутність плівки в досліджуваній області і, відповідно, неефективність хімічної обробки цих видів природного каменю через слабку взаємодію хімічних просочувальних речовин 3 породоутворюючими мінералами.

Висновки та перспективи подальших досліджень. Результати проведених досліджень:

1. Встановлено лінійні закономірності зміни колірних показників поверхні Буківського габро (Galant) та Покостівського гранодіориту (Grey Ukraine) залежно від його початкових колірних показників після хімічної обробки, що дозволяє визначати колірні показники поверхні природного каменю залежно від виду хімічної обробки;

2. Показники блиску поверхонь Буківського габро (Galant) є більшими і становлять 71,3 GU на відміну від Покостівського гранодіориту (Grey Ukraine), що має блиск 64,3 GU після механічної обробки. Максимальний показник блиску поверхні Буківського габро (Galant) становить 75,5 GU після обробки хімічним просочувальним засобом № 4 та після обробки засобом № 3 - 75,1 GU. Також після обробки 
поверхні Покостівського гранодіориту (Grey Ukraine) засобом № 3 показник блиску становить 71,8 GU i відповідає максимальній величині;

3. Зміна поглинання на певних піках зразків відповідних типів природного каменю після хімічної обробки вказують на характер фізико-хімічної взаємодії хімічних просочуючих речовин на поверхні природного каменю. Для певного типу природного каменю зміна поглинання буде більшою чи меншою при використанні певного виду хімічної обробки, що вказує на міцний або слабкий зв'язок хімічних просочуючих засобів з поверхнею природного каменю. За наявності слабких зв'язків може спостерігатися зачистка або непокриття наноплівкою, яка утворює хімічні агенти.

Зміна поглинання відповідно до типу природного каменю вказує на те, що:

1. Для Покостівського гранодіориту (Grey Ukraine) спостерігається сильна взаємодія з усіма хімічними засобами просочення;

2. Для Буківського габро (Galant) спостерігається більш сильна взаємодія 3 хімічними просочувальними засобами № $1,2$.

\section{References:}

1. Korobiichuk, V., Shamrai, V., Iziumova, O., Tolkach, O. and Sobolevskyi, R. (2016), «Definition of hue of different types of pokostivskiy granodiorite using digital image processing», Eastern-European Journal of Enterprise Technologies, No. 4 (5), pp. 52-57.

2. Korobiichuk, I., Korobiychuk, V., Nowicki, M., Shamrai, V., Skyba, G. and Szewczyk, R. (2016), «The study of corrosion resistance of Pokostivskiy granodiorites after processing by various chemical and mechanical methods», Construction \& Building Materials, No. 114, pp. 241-247.

3. Korobiichuk, I., Shamrai, V., Korobiychuk, V., Nowicki, M. and Szewczyk, R. (2015), «The study of the influence of natural stone surfaces polishing by different methods on the hues of lightness», 11th International Conference «Mechatronic systems and materials», pp. 105-106.

4. Dawei, W., Xianhua, C., Markus, O., Helge, S. and Bernhard, S. (2014), «Study of micro-texture and skid resistance change of granite slabs during the polishing with the Aachen Polishing», Wear, Vol. 318, Issues 1-2, pp. 1-11.

5. Hideo, A., Hidetoshi, T., Seong-Woo, K., Natsuko, A., Koji, K., Tsutomu, Y. and Toshiro, D. (2014), «Evaluation of subsurface damage in GaN substrate induced by mechanical polishing with diamond abrasives», Applied Surface Science, Vol. 292, pp. 531-536.

6. Xie, J. and Tamaki, J. (2007), «Parameterization of Micro-Hardness Distribution in Granite Related to Abrasive Machining Performance», Journal of Materials Processing Technology, Vol. 186, Issues 1-3, pp. 253-258.

7. Yavuz, H., Ozkahraman, T. and Demirdag, S. (2011), «Polishing experiments on surface quality of building stone tiles», Construction and Building Materials, Vol. 25, Issue 4, pp. 1707-1711.

8. Aldoasri, M.A., Darwish, S.S., Adam, M.A., Elmarzugi, N.A. and Ahmed, S.M. (2017), «Protecting of marble stone facades of historic buildings using multifunctional TiO2 nanocoatings», Sustainability, Vol. 9 (11).

9. Aflori, M., Simionescu, B., Bordianu, I.E., Sacarescu, L., Varganici, C.D., Doroftei, F. and Olaru, M. (2013), «Silsesquioxane-based hybrid nanocomposites with methacrylate units containing titania and/or silver nanoparticles as antibacterial/antifungal coatings for monumental stones», Materials Science and Engineering: B, Vol. 178, Issue 19, pp. 1339-1346.

10. Zarzuela, R., Carbú, M., Gil, M.A., Cantoral, J.M. and Mosquera, M.J. (2017), «CuO/SiO2 nanocomposites: a multifunctional coating for application on building stone», Materials \& Design, Vol. 114, pp. 364-372.

11. Corcione, C.E., Striani, R., and Frigione, M. (2013), «UV-cured siloxane-modified methacrylic system containing hydroxyapatite as potential protective coating for carbonate stones», Progress in Organic Coatings, Vol 76 (9), pp. $1236-1242$.

12. Gupta, U., Singh, V.K., Kumar, V. and Khajuria, Y. (2015), «Experimental and theoretical spectroscopic studies of calcium carbonate (CaCO3)», Materials Focus, Vol. 4, No. 2, pp. 164-169.

13. Corcione, C.E., Ingrosso, C., Petronella, F., Comparelli, R., Striccoli, M., Agostiano, A. and Curri, M.L. (2018), «A designed UV-vis light curable coating nanocomposite based on colloidal TiO 2 NRs in a hybrid resin for stone protection», Progress in Organic Coatings, Vol. 122, pp. 290-301.

14. Lyon, R.J.P., Tuddenham, W.M. and Thompson, C.S. (1959), «Quantitative mineralogy in 30 minutes, Econ. Geol. Vol. 54, pp. 1047-1055.

15. Lyon, R.J.P. and Burns, E.A. (1963), «Analysis of rocks and minerals by reflected infrared radiation», Econ. Geol., Vol. 58, pp. 274-284.

16. Hunt, G.R. (1970), «Visible and near-infrared spectra of minerals and rocks: I silicate minerals», Mod. Geol., Vol. 1, pp. 283-300.

17. Hunt, G.R., Salisbury, J.W. and Lenhoff, C.J. (1974), «Visible and near infrared spectra of minerals and rocks: IX. Basic and ultrabasic igneous rocks», Mod. Geol., Vol. 5, pp. 15-22.

18. Hunt, G.R. and Salisbury, J.W. (1976), Mid-Infrared Spectral Behavior of Metamorphic Rocks, Air Force Cambrigde Research Labs Hanscom AFB, Bedford MA, USA.

19. Lyon, R.J.P. (1965), «Analysis of rocks by spectral infrared emission (8 to 25 microns)», Econ. Geol., Vol. 60, pp. 715-736.

20. Vincent, R.K. and Hunt, G.R. (1968), «Infrared reflectance from mat surfaces», Appl. Opt., Vol. 7, pp. 53-59.

21. Riley, D.N. and Hecker, C.A. (2013), «Mineral mapping with airborne hyperspectral thermal infrared remote sensing at Cuprite, Nevada, USA», In Thermal Infrared Remote Sensing: Sensors, Methods, Applications, Springer, Dordrecht, The Netherlands, pp. 495-514. 
22. Kuosmanen, V., Arkimaa, H., Tiainen, M. and Bärs, R. (2015), «Hyperspectral close-range LWIR imaging spectrometry - 3 case studies», In Geophysical Signatures of Mineral Deposit Types in Finland; in Airo, M.-L. (ed.), Geological Survey of Finland, Espoo, Finland, Vol. 58, pp. 117-144.

23. Salisbury, J.W. and Walter, L.S. (1989), «Thermal infrared $(2.5-13.5 \mu \mathrm{m})$ spectroscopic remote sensing of igneous rock types on particulate planetary surfaces», J. Geophys. Res. Solid Earth, Corescan Pty Ltd., Denver, CO, USA, Vol. 94, pp. 9192-9202.

24. Lyon, R.J.P. (1964), Evaluation of infrared Spectrophotometry for Composition Analysis Lunar and Planetary Soils: Rough and Powdered Surfaces, Stanford Research Institute, Menlo Park, CA, USA, Part II, Contract NASR 49.

25. Hunt, G.R. and Logan, L.M. (1972), «Variation of single particle mid-infrared emission spectrum with particle size», Appl. Opt., Vol. 11, pp. 142-147.

26. Salisbury, J.W. and Eastes, J.W. (1985), «The effect of particle size and porosity on spectral contrast in the midinfrared», Icarus, Vol. 64, pp. 586-588.

27. Salisbury, J.W., Walter, L.S. and Vergo, N. (1987), Mid-Infrared (2.1-25 um) Spectra of Minerals, US Geological Survey, Reston, VA, USA, pp. 87-263.

28. Salisbury, J.W. and D'Aria, D.M (1994), «Emissivity of terrestrial materials in the 3-5 $\mu \mathrm{m}$ atmospheric window», Remote Sensing of Environment, Vol. 47, pp. 345-361.

29. Schodlok, M.C., Whitbourn, L., Huntington, J., Mason, P., Green, A., Berman, M., Coward, D., Conner, P., Wright, W., Jolivet, M. et al. (2016), «HyLogger-3, A visible to shortwave and thermal infrared reflectance spectrometer system for drill core logging: Functional description», Australian Journal of Earth Sciences, Vol. 63, pp. 929-940.

30. Hardgrove, C.J., Rogers, A.D., Glotch, T.D. and Arnold, J.A. (2016), «Thermal emission spectroscopy of microcrystalline sedimentary phases: Effects of natural surface roughness on spectral feature shape», JGR Planets, Vol. 121, pp. 542-555.

31. Kirkland, L., Herr, K., Keim, E., Adams, P., Salisbury, J., Hackwell, J. and Treiman, A. (2002), «First use of an airborne thermal infrared hyperspectral scanner for compositional mapping», Remote Sens. Environ, Vol. 80, pp. 447-459.

32. Ramsey, M.S. and Fink, J.H. (1999), «Estimating silicic lava vesicularity with thermal remote sensing: A new technique for volcanic mapping and monitoring», Bull. Volcanol., Vol. 61, pp. 32-39.

33. Kirkland, L., Herr, K., Keim, E., Adams, P., Salisbury, J., Hackwell, J. and Treiman, A. (2002), «First use of an airborne thermal infrared hyperspectral scanner for compositional mapping», Remote Sens. Environ., Vol. 80, pp. 447-459.

34. Osterloo, M.M., Hamilton, V.E. and Anderson, F.S. (2012), «A laboratory study of the effects of roughness on the thermal infrared spectra of rock surfaces», Icarus, Vol. 220, pp. 404-426.

35. Hardgrove, C.J., Rogers, A.D., Glotch, T.D. and Arnold, J.A. (2016), «Thermal emission spectroscopy of microcrystalline sedimentary phases: Effects of natural surface roughness on spectral feature shape», JGR Planets, Vol. 121, pp. 542-555.

36. Giancoli, D.C. (2005), «Physics: Principles with Applications», Pearson, New York, USA.

37. Bedford, R.E., Ma, C.K., Chu, Z.,Sun, Y. and Chen, S. (1985), «Emissivities of diffuse cavities. 4: Isothermal and nonisothermal cylindro-inner-cones», Appl. Opt., Vol. 24, pp. 2971-2980.

38. Fraden, J. (1993), AlP Handbook of Modern Sensors, American Institute of Physics, Springer, New York, USA.

39. Hapke, B. (1993), Theory of Reflectance and Emittance Spectroscopy, Cambridge University Press, Cambrige, UK.

Шамрай Володимир Ігорович - кандидат технічних наук, доцент Державного університету «Житомирська політехніка».

https://orcid.org/0000-0001-9441-9379.

Наукові інтереси:

- відкриті гірничі роботи;

- обробка природного каменю;

- раціональне природокористування;

- утилізація відходів гірничих підприємств.

Коробійчук Валентин Вацлавович - доктор технічних наук, професор, професор кафедри розробки родовищ корисних копалин імені Бакка М.Т. Державного університету «Житомирська політехніка».

https://orcid.org/0000-0002-1576-4025.

Наукові інтереси:

- видобуток та обробка природного каменю;

- гірництво.

Леонець Ірина Володимирівна - аспірант Державного університету «Житомирська політехніка». https://orcid.org/0000-0002-6572-681X.

Наукові інтереси:

- відкриті гірничі роботи. 